\title{
Psycholinguistic Aspects of Formation of Culture of Dialogical Communication*
}

\section{Психолінгвістичні аспекти формування культури діалогічного спілкування **}

\author{
Halyna Vaskivska ${ }^{1}$ \\ Dr. in Pedagogy, \\ Senior Researcher
}

\author{
Галина Васьківська ${ }^{1}$ \\ доктор педагогічних наук, \\ старший науковий співробітник
}

E-mail: gvaskivska@ukr.net orcid.org/0000-0002-8714-8512

Scopus Author ID: 57201066099

\section{Svitlana Palamar ${ }^{2}$}

Ph.D. in Pedagogy,

Senior Researcher

\section{Світлана Паламар²} кандидат педагогічних наук, старший науковий співробітник

E-mail: svetlana03@ukr.net orcid.org/0000-0001- 6123-241X Scopus Author ID: 57201058070

Lesia Poriadchenko ${ }^{2}$

Ph.D. in Pedagogy, Assistant Professor

\section{Леся Порядченко 2} кандидат педагогічних наук, доцент

E-mail: 1.a.poriadchenko@gmail.com orcid.org/0000-0001-8596-8907

\footnotetext{
* This study is done within the framework of the project (Registration number 586098-EPP-12017-1-UA-EPPKA2-CBHE-JP).

** Дослідження виконане в рамках проекту (реєстраційний номер 586098-EPP-1-2017-1UA-EPPKA2-CBHE-JP).
} 
Психолінгвістичні аспекти формування культури діалогічного...

\author{
${ }^{1}$ Institute of Pedagogy of \\ the National Academy of Educational \\ Sciences of Ukraine \\ 52-D, Sichovykh Striltsiv Str., \\ Kyiv, Ukraine, 04053
${ }^{2}$ Pedagogical Institute of the Boris
Grinchenko University of Kyiv
18/2, Igor Shamo b-r, Kyiv,
Ukraine, 02154

\author{
${ }^{1}$ Інституту педагогіки Національної \\ академї педагогічних наук України \\ вул. Січових Стрільців, 52-Д, \\ Київ, Україна, 04053
}

Original manuscript received August 11, 2018

Revised manuscript accepted August 29, 2019

\begin{abstract}
Introduction. The article presents the results of researching the samples of Englishspeaking literary heritage, which reveals psycholinguistic features of dialogical communication and peculiarities of communicants' perception of interactions meanings in dialogic speech. The technique of detecting the frequency of using different dialogues that differ in number of replicas is described. Objective. The purpose of the article is to characterize the psycholinguistic features of dialogical communication, to study units of the dialogue as means of forming a culture of communication of those who get aeducation.

Methods. The methods of analysis of domestic and foreign works of art, analysis of dictionary definitions, methods of contextual and logical-semantic analyzes, elements of statistical analysis are used in the article.

Results. It is substantiated that dialogue as a form of a communicative act is the most used form of verbal activity in which the text categories of communicants are implemented, their interpersonal relations are displayed, speech communication strategies appear, etc. Dialogue speech is characterized as a situational and thematic community of communicative motives in verbal statements consistently generated by two or more interlocutors in the direct act of communication. The frequency of the use of dialogues consisting of different amounts of dialogical unities is revealed. It is defined average number of dialogues consisting of dialogical unities; the frequency of dialogue with a different number of dialogical unities. It is considered the definitions of dialogue, dialogism, dialogical learning, dialogical speech, dialogical communication; it is characterized of the developed system of exercises and tasks for forming a culture of dialogical communication.
\end{abstract}

Conclusions. It is concluded that for the formation of a culture of dialogical communication of the educational recipients, it is of great importance to turn to highly artistic samples of literature for the purpose of emotional perception of them; creating situations of empathy with the characters of the work by "impersonation» 
Psycholinguistic Aspects of Formation of Culture of Dialogical...

in these images; work on dialogical situations; the use of dialogues as a means of socialization.

Key words: psycholinguistics, communicants, dialogical speech, dialogue, culture of communication.

\section{Introduction}

Effective interaction with the social environment is impossible without communication. Communication is a necessary condition for human life, without which it is impossible to fully formulate not only individual psychic functions, processes and properties, but also the person as a whole. The reality and necessity of communication is determined by the joint activity: to live, people are forced to interact. From the moment of birth, a person communicates with other people, but sometimes people who have significant achievements in the knowledge of the material world are helpless in the field of communication; therefore, it is necessary to study the rules of interaction with people in order to become a socially capable member of society. That is, communication is effective only when people who interact with each other are competent in a particular case.

Consequently, there is a need to form a communicative competence to improve the ability to build relationships with the environment, keep the word in front of the audience and develop the skills to voice their thoughts, to publicize your own views and beliefs.

The need for communication can be caused by different needs: the desire to compensate for internal tension or relieve anxiety; hear the approval of their actions; get or refine your idea of another person, about his/her abilities; actively influence the opinion of another person, change his/her views, persuasion; to show concern about other problems; present yourself as a personality, etc.

The linguistic act, as the minimum unit of speech activity, is allocated and studied in the theory of speech acts - the doctrine, which is one of the most important components of psycholinguistics. Therefore, speech activity can not take place outside the «desire to compensate for internal tension or to relieve anxiety; hear the approval of their actions; get or refine your idea of another person, about his/her abilities; 
actively influence the opinion of another person, change his/her views, persuasion; to show concern about other problems; presenting oneself as a personality, etc.» (Vaskivska, H., 2016: 36).

The first attempts to analyze the language from a psychological point of view were made only in the 60's and 70's of the XX century. Since then, interest in linguistic research in new areas has grown. The further development takes place in the late 1940's by the Oxford analyst J. Austin, the theory of speech acts, one of which is that the speech act is the unit of communication. The American philosopher J. Searle continued to explore the theory of speech acts. He substantiates the assertion that a speech act is a certain activity.

Dialogism, dialogicity, dialogue training, dialogical speech, dialogic communication - these concepts in recent decades have become a field of scientific interests of many researchers (Dafermos, 2018; Hoffmanova, 1993; Linell, 2003; Motta, Rafalski, Rangel \& de Souza, 2012).

Dialogue training helps to realize the developmental, sociocultural and research functions of education (Sitarov, 2004). Researcher V. Grigoryeva (2007) includes to the means of dialogue of the text: pronouns and verbal forms; syntaxes; texture and compositional means; averbal means. Dialogism in the theory of communication is a word, a special construction of speech, inherent in the dialogue (Laguta (Aljoshina), 2000).

Thus, from the linguistic point of view, «dialogism» is a word, a special construction of speech, inherent in the dialogue (Laguta (Aljoshina), 2000), and on the other hand, the starting point of the philosophy of dialogue, indicating on the importance of dialogism and dialogue both in didactics and in the pedagogical practice of high school, in which senior students' skills of dialogical communication are formed.

Therefore, culture is dialogical, as S. Garrod (2002) notes, because the dialogue helps to clarify different views, forms a critical setting, prompts seek the answer to the question. T. Adamjyants (2003) notes that the dialogicity of communication plays an extremely important role in the system of human-environmental metabolism, which means that sociocultural reproduction is determined as such.

The main purpose of this work is to reveal the psycholinguistic features of dialogical communication; research of the unit of dialogue, dialogical unities, which will promote the effectiveness of the formation of a culture of communication. 


\section{Methods and techniques of research}

(the theoretical and methodological procedure and/or experimental research is considered)

The methodology of the research is complex with using methods of analysis of native and foreign artistic works, analysis of vocabulary definitions, methods of contextual and logical-semantic analysis, elements of statistical analysis. The study of classical samples was performed in order to identify the psycholinguistic aspects of the formation of a dialogical communication culture. Due to the study of the frequency of use of different dialogues, the classification of dialogical unities was made, the limits of semantic perception and concentration of attention of the listener were determined. The communicative intention of the speaker (Ivanova, Burlakova \& Pocheptsov, 1981) was investigated. Considered performative verbs, that is, verbs that characterize the relationship between the addressant and the addressee in the speech act (Zasyekin, 2010). The correlation between the formal signs of the sentence and its communicative orientation was studied. In the circle of our interests was a theoretical analysis of procedural knowledge of the language, which became the basis of speech skills, and hence the skills of dialogical communication (Gorelov \& Sedov, 2004); psycholinguistic features of different types of discourse (Kalina, 2000).

\section{Results and Discussions}

One of the most important directions in modern linguistics is the study of the functioning of speech units, as well as the relationship between speech, speaker and the situation of communication in the aspect of human activity, which is the subject of research in psycholinguistics. Communication is carried out in the form of monologues and dialogical texts. Dialogue, like any text, has the following features: integrity, typological and stylistic features, semantic peculiarities and themerhetorical division.

The integrity of the dialogue manifests itself in its coherence and secrecy. The separation of the dialogue lies in the fact that it has certain limits - the beginning and the end of the conversation. Dialogue connectivity is a direct reflection of the connectivity of its components (replicas), the nature and mode of communication are ambiguous and can 
be accomplished by different lexical-grammatical means. Researchers in the field of syntax of dialogical speech recognize that repetition of words and reciprocation is one type of structural and semantic communication replicas of communicants (the respondent statements completely or partially repeat the structure and linguistic composition of the initial statement, repetitions and reciprocation automatically follow the original speech of the speaker and express only an emotional attitude to the content of the statement, acting through means of the coherence of dialogical unities) (Zahnitko \& Domracheva, 2001).

The second sign of a dialogue is typological and stylistic features (the speaker plays an important role - his idea of the situation in which the communication takes place, the place and status of the recipient in this situation). These features determine the communicative installation of the speaker (style, genre, volume, structure of sentences, choice of words, etc.).

The third sign of a dialogue is semantic peculiarities (the ability to store and transmit certain information in the course of communication). From this point of view, the dialog contains information other than what is contained in its constituent elements.

The fourth sign of a dialogue is the theme-rheumatic division, which has its own peculiarities. For example, the first replica (initiatory) can take the form of a question, the second (reactive) - to be the answer. The subject of the statement can be identified with the content of the question, and the remake - with the part of the information that is the direct answer to the question.

From a linguistic point of view, dialogue is a coherent text that consists of autonomous pairs of replicas, that is, dialogical unities: the expression of opinions and their perceptions, the response to them, which is reflected in the structure of this speech act. Dialogical unity can be defined as a sequence of two interrelated utterances of two different speakers, in which the second statement always responds to the first (Richards, Platt J. \& Platt H., 1999):

«Can you tell us if there's a farm near here where we could stay the night? I've gone lame.»

«There's only our farm near, sir.» She spoke without shyness, in a pretty soft voice (The Things He Loves, 2001: 174). Therefore, in this situation, the first part of dialogical unity is the question, and the second, respectively, is the answer to it. 
Psycholinguistic Aspects of Formation of Culture of Dialogical...

Thoroughly investigating DU, the American analyst G. Sachs identifies the first and second parts of unity (Mey, 2001).

For example, if the first part is a request, a question, an order, etc., then the second part, respectively, will be the fulfillment/non-fulfillment of the request, the answer to the question, the agreement/disagreement to execute the order, etc. (Vaskivska, O., 2016).

By analyzing the structural elements of dialogical unities by their communicative type, we propose to classify them into large three groups according to the first component of the DU. Therefore; in the first group it will be a question, in the second - the statement, and in the third an outspoken sentence. The first group will include dialogical unities of the type:

DU «question - question»:

«Really, I can't bear to hear you sneeze like that,» cried our hero. «Have you ever tried the Quetch at the Rat Trap Club?»

«What Quetch?» asked the other, between sneezes (English Short Stories..., 1988: 334);

DU «question - statement»:

«And you were happy?» asked Mr. Pyne.

«I was. He was a good man to me, Abner...» (English Short Stories..., 1988: 306);

DU «question - exclamation»:

«Do you ever have time to do anything for yourself?»

«Oh! Well...» (The White Stocking, 2001: 186);

DU «question - outspoken sentence»:

«And where exactly did you come in?»

«Oh, don't be so silly!» she laughed (English Short Stories..., 1988: 153).

Although in all four cases, the first part of the DU is different in grammatical form and content of the question (general, inductive, special), but common for them are the presence of a specific questioning intonation and the structurally expressed idea of the information gap in the speaker's knowledge of the content of the utterance. That is, the question is always the request of an unknown message speaker (Ivanova, Burlakova \& Pocheptsov, 1981; Lee, 1990).

When exploring the second part of dialogical unity, it should be noted that the answer to the question may be: question in the case when the addressee asks or clarifies the content of the question to prevent 
communicative failure; statement, that is, the message unknown to the information speaker; exclamation expressing the emotions of the addressee, not naming them; and an outspoken sentence, the shape of which may vary, but the characteristic feature will always be the specific intonation in oral speech and the presence of an exclamation mark in the written form.

The next group includes dialogical unity, in which the first element is the statement:

DU «statement - statement»:

«We're Indians,» he reminded her savagely.

«I don't want to be an Indian,» she said (English Short Stories..., 1988: 363);

DU «statement - question»:

«Ah, you've drunk your soup, my dear. That's good. You'll be better soon.»

«When was I taken ill?» asked Mrs. Rymer (English Short Stories... 1988: 313);

DU «statement - exclamation»:

«Yes, don't make her weep,» said Mark. «We had to rent Willowdale. You see, we have to pay the taxes on this place. Twentyeight rooms! You can't rent it, you can't sell it. So we had to move in. Here's the gate. Now you'll see it».

«Dear me!» said Mr. Murchison. «Dear me!» (English Short Stories... 1988: 346);

DU «statement - outspoken sentence»:

«Oh, yes. Diana Lucas will be with us.»

«Diana! How lovely!» (The Things He Loves, 2001: 260).

Consequently, in each situation, the statement contains certain information about the events, thoughts or feelings that the speaker wants to convey to the listener. Accordingly, the reactions of the recipient may be different. Therefore, in the first case, the listener adds some new information to the already known. In addition, the response to the message of information may be: a question in the case when information is not enough or it is specified; exclamation and outspoken sentence as an expression of an emotional state of the listener.

The third group contains dialogical unities, in which the role of the first element is an outspoken sentence:

DU «outspoken sentence - statement»: 
Psycholinguistic Aspects of Formation of Culture of Dialogical...

«What an interesting creature that must be!» cried Mr. Beaseley in a rapture.

"Yes, yes,» said the Portuguese. «It is certainly interesting.» (English Short Stories..., 1988: 341);

DU «outspoken sentence - question»:

«Hi! Chadwick!»

«What's up?» asked Chadwick, unwillingly stopping. (The White Stocking, 2001: 20);

DU «outspoken sentence - outspoken sentence»:

«Now then, hurry up, please!» he said coldly.

«Right on! Your majesty,» said another of the men, and they all three laughed (The White Stocking, 2001: 14).

Consequently, on emotionally colored sentences, the listener can respond in different ways: to report or to ask certain information, thereby maintaining the emotional state of the speaker; and express their own emotions.

Consequently, we investigate the feasibility of using selected samples of English texts in the process of forming a culture of dialogue communication with the consideration of the peculiarities of percepting the meanings of speech acts. We analyze the frequency of the use of dialogues with a variety of dialogical unities on the example American and English authors.

Therefore, for example, the message «I will be there in time» can be considered as a planned action: «I declare that I will be there in time», a promise: «I promise you that I will be there in time»; a threat: «I warn I'll be there in time».

The speaker can pronounce sentences with different intonation every time. In this case, an attention should be paid to the context in which the sentence occurs.

Taken into considerarion that the dialogue is two-sided, it means that the interlocutors take turns speaking and listening, both communicators should follow the rules of communication. First of all, scientists are pointing out rules for the speaker.

Rule 1. One of the most important rules for a speaker is a friendly attitude to the interlocutor, respect for the addressee.

«So this is my patient?» he said in a low, vibrant voice.

«I'm not a patient,» said Mrs. Rymer. 
«Your body is not sick,» said the doctor, «but your soul is weary. We of the East know how to cure that disease. Sit down and drink a cup of coffee.»

Mrs. Rymer sat down and accepted a tiny cup of the fragrant brew. As she sipped it the doctor talked.

«Here in the West, they treat only the body. A mistake. The body is only the instrument...». (English Short Stories..., 1988: 309).

Rule 2. The speaker must be politely relevant in a particular situation. The most common form of a polite attitude is conversion. The most common function is the nouns, which denote proper or common names.

- My old friend, - I said, lifting him up and helping him get to bed. - Are you cold? Why didn't you flood the fireplace?

- I'm not cold at all, - he replied. - No need to light the fire, no need! I'm coming from here, my pigeon, - he said further, looking at me with the last, fading, dim gaze... (Balzak, 2004: 76).

Rule 3. The speaker is not recommended to put his / her «I» in the center of attention, to impose his / her own thoughts and to evaluate the events. It is necessary for him / her is to separate his / her «I» into the center of attention.

Example: «Your proposition interests me,» said Mr. Pyne. «You do not mention a country house.»

«I forgot it, but I've got one. Bores me to death.»

«You must tell me more about yourself. Your problem is not easy to solve.» (English Short Stories..., 1988: 306).

Rule 4. The speaker needs to be able to choose a topic for conversation, which is appropriate in any situation that is interesting, understandable to the partner. For example:

«Hello, Dad. It's Jason. I've got some great news.»

«I can't hear you, son. There's a terrific racket going on behind you. Where are you calling from?»

«The whole squash team's in my room. They just voted for next year's varsity captain and for some stupid reason they chose me.»

«Son, that's just terrific news. I can't wait to tell your mother...» (Segal, 1986: 142).

Rule 5. The speaker must follow the logic of the text's development, so that the conclusions do not contradict the intent of the conversation. Consider the situation: 
Psycholinguistic Aspects of Formation of Culture of Dialogical...

«The flowers are sweet-scented,» he said. «Where do they come from?»

«From the garden - under the windows,» said Isabel.

«So late in the year - and so fragrant! Do you remember the violets under Aunt Bell's south wall?»

The two friends looked at each other and exchanged a smile. (English Short Stories..., 1988: 255).

Rule 6. The addressee must constantly select language means according to the chosen tone of the text, focusing not only on the addressee but also on the communication situation in general, on the formality or informality of the situation.

Rule 7. The speaker should keep in mind that the limits of the sense perception and concentration of the listener are limited.

Attention is a form of human psychological activity that reflects itself in his/her focus on certain objects while abstracting from others (Voytko, 1982).

Rule 8. The next rule for the speaker is the following: the speaker should remember that in the process of an oral contact direct communication, the listener not only hears but also sees him / her, so, he perceives gestures, facial expressions, postures, general manner of speaking and culture of behavior.

The dialogue speech is characterized by the significant usage of non-verbal means of communication. The non-verbal signs themselves make the largest difference between an oral speech and a written speech. If there is only one channel of information (a text) in a written speech, then the oral speech has two channels of information: a text (spoken words) and an intonation, some facial expressions, gestures, etc. The other channel is extremely important during a process of communication (Kochergan, 1999).

It is also worth taking into consideration that in a spontaneous speech, when it is difficult to find the right word, it is replaced with a gesture:

«You can't go on,» - Korazov said. - For you to trust your doctor, I will finish your story myself. The husband of this young lady is a very rich man, or perhaps she herself belongs to a higher local aristocracy, and she obviously has something to be proud of».

Julien nodded silently; he lacked the courage to speak (Stendal, 2017). 
Therefore, non-verbal means of communication play a significant role in the oral communication, especially in a dialogue. They can carry some additional information, rethink what they say, or even replace words that should be kept in mind for communicators.

So, we conclude that the content and nature of a dialogical communication is influenced by: the perception of the interlocutor and orientation in the situation; the content part of the utterance; speech processing of thoughts and perception of the partner's replies on communication.

\section{Conclusions}

The peculiarities of dialogical communication as a means of forming a culture of dialogical communication of the educational recipients can be provided by developing appropriate tasks. They should be communicative in nature and, at the same time, require some complex knowledge of different subjects and disciplines. Their purpose is encourage to communicative self-determination of the recipients of education; a creation of appropriate conditions for mastering and implementing skills of communicative interaction, for using the acquired knowledge and skills in practice, in non-standard situations. So, it is necessary to use communicative tasks.

A common function of an educational dialogue in the pedagogical process is the transfer of information, social experience and cultural heritage of the mankind and the certain society by adequate means. At the same time, in the process of information assimilation, there is also a formation of a certain outlook, which is determined not only by forms of educational interaction, but also by the content of education. The dialogue of consciousness requires a construction of the learning content as a dialogue, the «polyphony of cultures' voices» of different epochs, a set of problems.

Therefore, to form a culture of dialogical communication of the educational recipients, it is a great importance to turn to highly artistic literature samples for the purpose of emotional perception of them; creating situations of empathy with characters of the work by means of «getting along» with the image; to work on dialogical situations; to use dialogues as a means of socialization. In short, the skill of the 
Psycholinguistic Aspects of Formation of Culture of Dialogical...

artist is not only a fascinating plot. It is his / her face, painted with an artistic text, complete, eventful not only with the description of events themselves, but also with the experiences of the characters, with the peculiarities of their dialogical speech, because we see not only the master's pen, but also the linguocognitive (linguistic) activity of the characters.

\section{References}

Adamjyants, T.Z. (2003). Semiosotsiologiya, ili semiosotsiopsikho-logicheskaya paradigm [Semisociology or semiosociopsycho-logical paradigm]. In V.L. Abushenko \& G.M. Yeveljkin (Eds.), Sociology: Encyclopedia Sotsiologiya: Entsiklopegiya (pp. 1000-1038). Minsk: Knizhnyy Dom [in Russian].

Balzak, O.D. (2004). Etiudy pro zvychai: stseny pryvatnoho zhyttia [Studies about customs: scenes of privacy]. Kharkiv: Folio [in Ukrainian].

Dafermos, M. (2018). Relating dialogue and dialectics: a philosophical perspective. Dialogical Pedagogy: An International Online Journal, 6, 1-18. https://doi. org/10.5195/DPJ.2018.189

English Short Stories of the 20th Century. (1988). The Collection of Short Stories. Retrieved from https://www.goodreads.com/book/show/7519233-20th-centuryenglish-short-stories

Garrod, S. (2002). The challenge of dialogue for theories of language processing. In G.T.M. Altman (Ed.), Psycholinguistics: Critical Concepts in Psychology (Vol. 3, pp. 464-488). N.Y.: Routledge.

Gorelov, I.N., \& Sedov, K.F. (2004). Osnovy psykholingvistiki [Fundamentals of psycholinguistics]. Moscow: Labirint [in Russian].

Grigoryeva, V.S. (2007). Diskurs kak element kommunikativnogo protsessa: pragmalingvisticheskiy $i$ kognitivnyy aspekty [Discourse as an element of the communicative process: pragmalinguistic and cognitive aspects]. Tambov: Izd-vo Tambov. gos. tehn. un-ta [in Russian].

Hoffmanova, J. (1993). Zwischen Dialog und Monolog. Dialoganalyse: Referate der Arbeitstagung, 5, 35-40 [in German].

Ivanova, I.P., Burlakova, V.V., \& Pocheptsov, G.G. (1981). Teoreticheskaja grammatika sovremennogo anglijskogo jazyka [Theoretical grammar of modern English]. Moscow: Vysshaja shkola [in Russian].

Kalina, N.F. (2000). Analiz diskursa V psihoterapii [Discourse analysis in psychotherapy]. Psihologicheskiy zhurnal - Psychological journal, 2(21), 100107 [in Russian].

Kochergan, M.P. (1999). Vstup do movoznavstva [General Linguistics: textbook]. Kyiv: Academy [in Ukrainian].

Laguta (Aljoshina), O.N. (2000). Stilistika. Kul'tura rechi. Teoriya rechevoy kommunikatsii [Stylistics. The culture of speech. Theory of speech communication]. Novosibirsk: Izd-vo Novosib. gos. un-ta [in Russian].

Lee, C.J. (1990). Some hypotheses concerning the evolution of polysemous words. Journal of Psycholinguistic Research, 19, 211-219. https://doi.org/10.1007/ BF01077257 
Linell, P. (2003). Essentials of dialogism. Aspects and elements of a dialogical approach to language, communication and cognition. Sweden.

Mey, J.L. (2001). Pragmatics. An Introduction. Second Edition. Malden. Massachusetts: Blackwell Publishers Inc.

Motta, F.E, Rafalski, J.C., Rangel, I.C., \& de Souza, M.L. (2012). Narrative and Dialogical Refl exivity: An Approach between Writing and Inner Speech. Psicologia: Refl exao e Critica, 26(3), 609-616. https://doi.org/10.1590/S010279722013000300021

Richards, J., Platt, J., \& Platt, H. (1999). Longman Dictionary of Language Teaching and Applied Linguistics. Harlow: Pearson Education Limited.

Sitarov, V.A. (2004). Didaktika [Didactics]. Moscow: Akademiya [in Russian].

Segal, E. (1986). The Class. New York: Bantam Rack-size Edition.

Stendal, F. (2017). Chervone $i$ chorne [Red and black]. Kyiv: Znannya [in Ukrainian].

The Things He Loves. (2001). The Collection of Short Stories. Retrieved from https:// www.goodreads.com/book/show/7519233-20th-century-english-short-stories

The White Stocking. (2001). The Collection of Short Stories. Retrieved from https:// www.goodreads.com/book/show/7519233-20th-century-english-short-stories

Vaskivska, O.Ye. (2016). Navchaiemos dialohichnoho spilkuvannia: kurs za vyborom: eksperymentalnyi posibnyk [We learn dialogical communication: elective course: experimental guide]. Kyiv [in Ukrainian].

Vaskivska, H.O. (2016). Formuvannya komunikatyvnoyi kompetentnosti osobystosti yak osnovna problema suchasnoyi lingvodydaktyky [Formation of the communicational competences of the person as one of the main problems of temporary lingvodidactics]. Naukovyj visnyk Sxidnoyevropejskogo nacionalnogo universytetu imeni Lesi Ukrayinky - Scientific herald of the Lesia Ukrayinka Eastern European National University, 1, 33-38 [in Ukrainian].

Voytko, V.I. (1982). Psykholohichnyi slovnyk [Psychological dictionary]. Kyiv: Higher school [in Ukrainian].

Zahnitko, A.P., \& Domracheva, I.R. (2001). Osnovy movlennievoi diialnosti [The basis of speech activity]. Donetsk: Ukrainskii Kulturolohichnyi Tsentr [in Ukrainian].

Zasyekin, S. (2010). Translation as a psycholinguistic phenomenon. Journal of Psycholinguistic Research, 39(3), 225-234. https://doi.org/10.1007/s10936-0099134-2

\section{АНОТАЦІЯ}

Вступ. У статmі подаються результати дослідження зразків англомовної літературної спадщини, на яких розкриваються психолінгвістичні особливості діалогічного спілкування i особливості сприймання комунікантами смислів інтеракцій у діалогічному мовленні. Описана методика виявлення частотності вживання різних діалогів, що відрізняються за кількістю реплік. Мета. Схарактеризувати психолінгвістичні особливості діалогічного спілкування, дослідити одиниці діалогу як засобу формування культури спілкування здобувачів освіти.

Mетоди. У статті використано методи аналізу вітчизняних і зарубіжних художніх творів, аналіз словникових дефініцій, методи контекстуального та логіко-семантичного аналізів, елементи статистичного аналізу. 
Psycholinguistic Aspects of Formation of Culture of Dialogical...

Результати. Обгрунтовано, що діалог як форма комунікативного акту $\epsilon$ найбільш вживаною формою словесної діяльності, в якій реалізуються текстові категорії комунікантів, відображаються їх міжособистісні відносини, проявляються мовленнєві стратегії спілкування та ін. Діалогічне мовлення схарактеризовано як ситуативно-тематичну спільність комунікативних мотивів в усних висловлюваннях, послідовно породжених двома або більше співрозмовниками в безпосередньому акті спілкування. 3'ясовано частотність вживання діалогів, що складаються з різної кількості діалогічних єдностей. Визначено середню кількість діалогів, що складаються з діалогічних єдностей; частоту вживання діалогів з різною кількістю діалогічних єдностей. Розглянуто поняття діалогізачія, діалогічність, діалогове навчання, діалогічне мовлення, діалогічне спілкування; схарактеризовано розроблену систему вправ і завдань щодо формування культури діалогічного спілкування.

Висновки. Доведено, що для формування культури діалогічного спілкування здобувачів освіти велике значення має звернення до високохудожніх зразків літератури з метою емочійного їх сприйняття; створення ситуацій співпереживання з героями твору шляхом "вживання» в ці образи; робота над діалогічними ситуаціями; використання діалогів як засобів сочіалізації.

Ключові слова: психолінгвістика, комуніканти, культура спілкування, діалогічна $\epsilon$ нність.

\section{Васьковская Галина, Паламар Светлана, Порядченко Леся. Психолингвистические аспекты формирования культуры диалогического общения}

\section{АННОТАЦИЯ}

Вступление. В статье представлены результаты исследования образцов англоязычного литературного наследия, на которые раскрываются психолингвистические особенности диалогического общения и особенности восприятия коммуникантами смыслов интеракций в диалогической речи. Описывается методика выявления частотности употребления разных диалогов, отличающихся по количеству реплик. Цель. Охарактеризовать психолингвистические особенности диалогического общения, исследовать единицы диалога как способа формирования культуры общения учащихся.

Методы. В статье использованы методы анализа отечественных $и$ зарубежных художественных произведений, анализ словарных дефиниций, методы контекстуального и логико-семантического анализа, элементы статистического анализа.

Результаты. Обосновано, что диалог как форма коммуникативного акта наиболее употребляемая форма словесной деятельности, во время которой реализуются текстовые категории коммуникантов, отображаются их межличностные отношения, проявляются языковые стратегии общения и др. Диалогическая речь охарактеризована как ситуативно-тематическая общность 
Психолінгвістичні аспекти формування культури діалогічного...

коммуникативных мотивов в устных высказываниях, последовательно порождаемых двумя или больше собеседниками в непосредственном акте общения. Выяснена частотность употребления диалогов, состоящих из разного количества диалогических единств. Определено среднее количество диалогов, состоящих из диалогических единств; частоту употребления диалогов с разным количеством диалогических единств. Рассмотрены понятия диалогизация, диалогичность, диалоговое обучение, диалогчческая речь, диалогическое общение; охарактеризовано разработанную систему упражнений и задач по формированию культуры диалогчческого общения.

Выводы. Доказано, что для формирования культуры диалогического общения учащихся большое значение имеет обращение $к$ высокохудожественным образцам литературы с целью их эмоционального восприятия; создание ситуаций сопереживания с героями произведения путем «внедрения» в эти образы; работа над диалогическими ситуациями; использование диалогов как средство социализации.

Ключевые слова: психолингвистика, коммуниканты, культура общения, диалогическое единство. 